\title{
THE STATUS AND DISTRIBUTION OF THE COMMON POORWILL IN THE CYPRESS HILLS, SASKATCHEWAN
}

\section{MATINA C. KALCOUNIS, RYAN D. CSADA and R. MARK BRIGHAM, Dpartment of Biology, University of Regina, Regina, Saskatchewan. S4S OA2}

Common Poorwills are nocturnally active, insectivorous birds. They are best known for their physiological ability to enter torpor and their alleged ability to hibernate. ${ }^{2,3,8}$ Common Poorwills (henceforth poorwills) are known from only two restricted localities in Canada, both of which represent the northern limit of their ranges. ${ }^{7}$ Very little is known about their habitat requirements, population status, or reproductive biology at either of these locations. One population is centred in the Okanagan Valley of south-central British Columbia. ${ }^{5}$ This is the only Canadian population for which there is more than one breeding record. ${ }^{6}$ The second locale is the Cypress Hills and the Great Sand Hills regions of southwestern Saskatchewan.

The Cypress Hills, a geological and topographical plant and animal refuge, lie isolated on the Canadian prairies. ${ }^{11}$ Cypress Hills Provincial Park in Saskatchewan (Figure 1; henceforth the park will be referred to as Cypress Hills) consists of two distinct geographical units, Centre Block and West Block. There are a total of 25 records for poorwills in the Cypress Hills and the lower
Frenchman River Valley. ${ }^{13}$ There is one confirmed breeding record in the West Block, however, to our knowledge there has been no rigorous attempt to determine the status of poorwills in this region. The purpose of our study was to determine if poorwills were resident within the West Block and, if present, to evaluate distribution, population size, reproductive status and habitat use.

\section{METHODS}

Population Size The study was conducted in the West block from 22 May through 3 September 1991. We also made brief surveys of the Centre Block (on two nights), the Great Sand Hills (one night), and the Frenchman River Valley near Eastend (one night; Figure 1).

Since caprimulgids respond to song playbacks, an estimate of population size can be made by listening for response along transects through representative habitats. ${ }^{9,10}$ During the study period we played tapes of recorded poorwill calls along 16 transects (total distance of $71 \mathrm{~km}$ ) on a total of 49 nights (Table 1, Figure 2). Playbacks were conducted at $300 \mathrm{~m}$ intervals along each transect in a manner similar to Kepler and 
Kepler's census of whip-poor-wills. ${ }^{9}$ Transects mostly followed gravel roads and dirt trails, however, we also walked to some areas not accessible by road. Censusing efforts were concentrated during periods with moonlight since poorwills are most active at dusk, dawn and during periods with lunar light. ${ }^{4}$

Orr, Aldrich and limited data from the British Columbia population (R. $M$. Brigham, unpub. data) suggest that poorwills mate monogamously. ${ }^{1,12}$ Assuming that only males call and that all males acquire a mate, an estimate of the total population can be made by doubling the number of males heard calling.

Reproductive Status We attempted to capture poorwills at four sites (Figure 2). Mist nets (6-15 m long) were erected shortly before sunset and playbacks were used to lure the birds. Nets were usually left open for two to three hours per night (14 nights in total), although on moonlit nights they were left up longer. Radio transmitters (Holohil Systems Inc.) were affixed in a back pack arrangement on two captured individuals. ${ }^{3}$

Birds carrying transmitters were located on a regular basis during the daytime (usually every second day) to find nest sites and to determine where non-nesting or incubating individuals roosted. Nocturnal tracking of foraging birds was done at irregular intervals between periods of censusing and trapping.

Habitat Use We assessed habitat use from direct observations, the locations of calling birds, and tracking data from foraging or roosting birds.

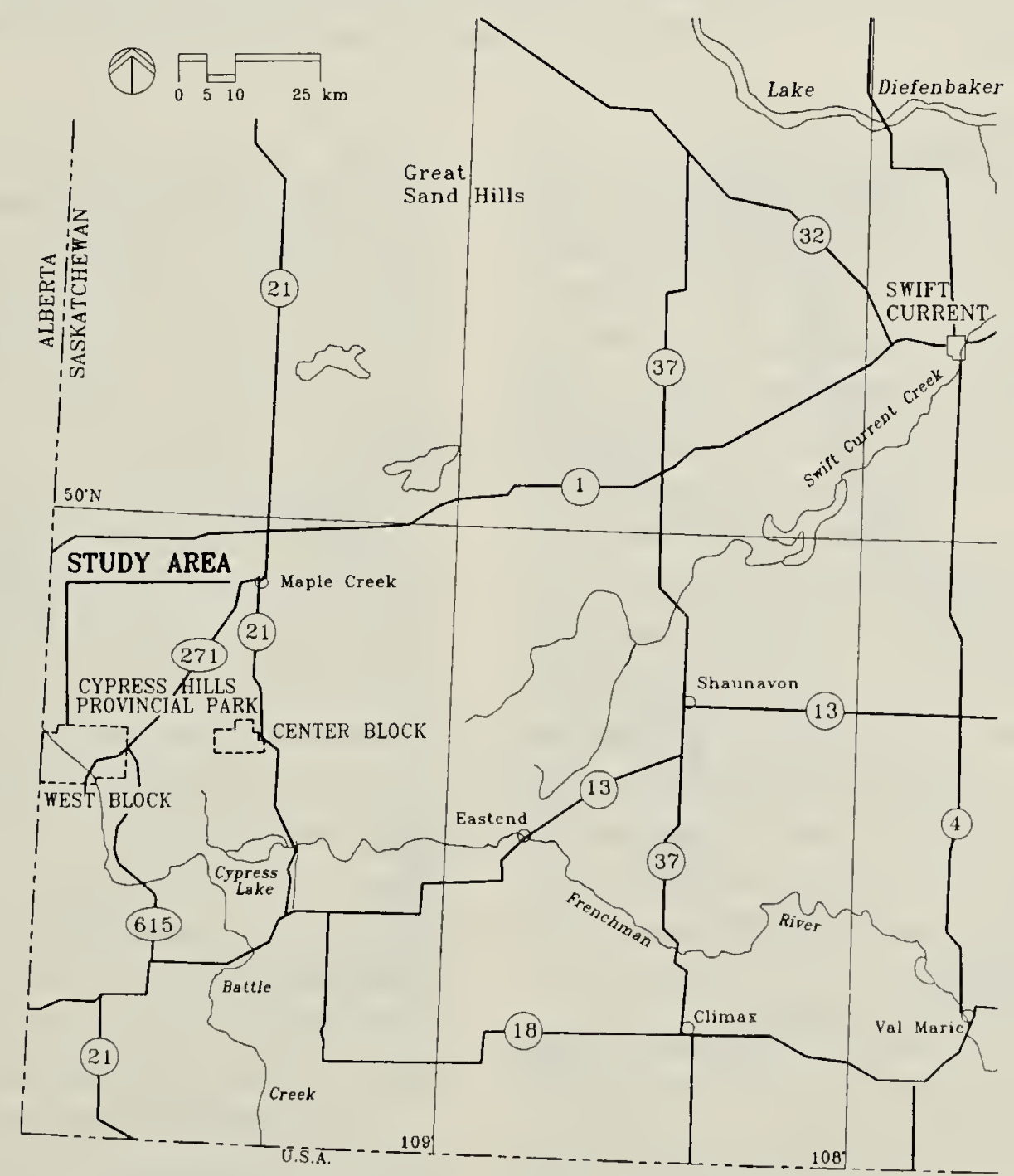

Figure 1. Regional context of study area. 


\section{RESULTS}

Population Size During the 49 survey nights, 55 poorwills responded to our playbacks and 24 were seen (Table 1). The first was heard on 27 May (11 days after the first was heard in the Okanagan Valley). A conservative estimate of the number of male poorwills was made by using the count from the night with the highest number of responses from, or sightings of, different individuals along each transect (Table 1). In general, calls within $100 \mathrm{~m}$ of each other were considered to be one bird. Calling clusters more than $250 \mathrm{~m}$ apart were interpreted as different birds. Using these criteria, we estimate that a minimum of 30 male poorwills were resident in the West Block during 1991. Assuming that each male acquired a mate, the minimum number of poorwills in the area we surveyed was 60 .

Poorwills ceased calling in the West Block in mid- to late July. This includes unsolicited calling as well as calling in response to our playbacks. We know this to be the case since the radio-tagged birds, whose location was known, did not respond to playbacks after this time.

There were no responses to our playbacks in the Centre Block, however one bird responded in the Frenchman River Valley and two responded in the Great Sand Hills.

Reproductive Status We caught one male and one female poorwill and outfitted each with a transmitter (Table 2). We located their "nest" and clutch of two eggs. The eggs hatched on 22 and 23 July and the chicks were checked periodically

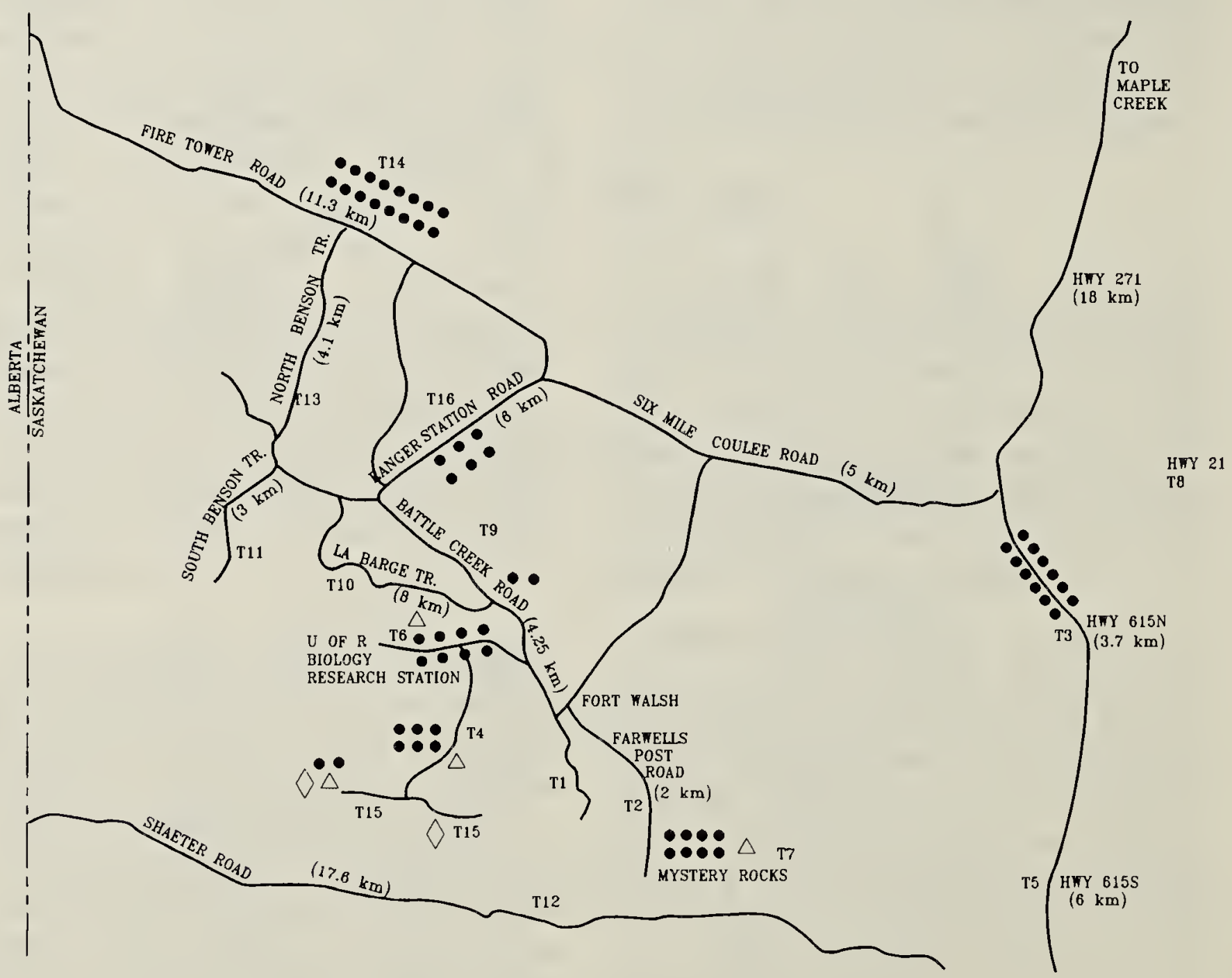

Figure 2. Poorwills sighted/heard Cypress Hills Provincial Park - West Block. 


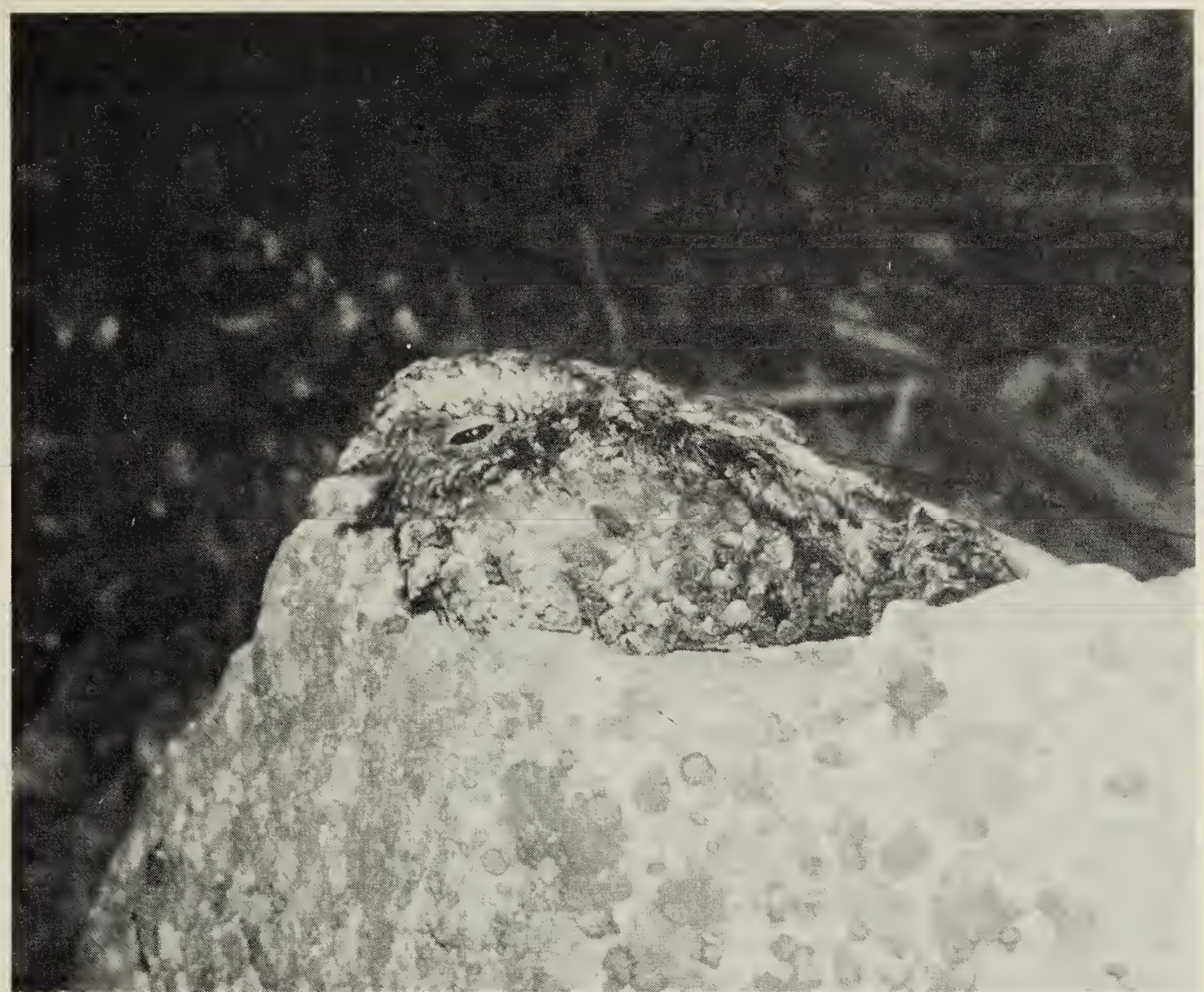

Male poorwill roosting on a rock near Vaseaux Lake, B.C.

Mark Brigham

(approximately every three days). They disappeared between noon on 1 and noon on 2 August. At that time, the oldest chick was only ten days old and not able to fly. We assume the nestlings were preyed upon. Interestingly, on 1 August, the first egg of a new clutch was laid. A second egg was laid on 2 August. Direct observations and tracking data indicated that the male and female shared incubating and brooding duties during both breeding attempts. The first chick in the second clutch hatched on 21 August and the second on 22 August and they were both healthy and growing at the end of our study on 3 September. The tagged adult birds departed from the area on 22 September, however we do not know the fate of the young.

Habitat Use The vegetation pattern of West Block consists of open side hills, dominated by Timber Oat Grass (Danthonia intermedia), Club Moss (Selagenella densa) and Creeping Juniper (Juniperus horizantalis). Intermixed are stands of Lodgepole Pine (Pinus contorta), White Spruce (Picea glauca) and Trembling Aspen (Populus tremuloides). Tracking suggests that foraging by poorwills occurred over these side hills, which approach $1300 \mathrm{~m}$ in elevation, and over gravel roads and dirt trails. Poorwill activity was not restricted to the side hills, however, as birds frequently roosted on low branches of dead trees at the forest edge and also foraged along forest edges.

The distribution of poorwills appears clumped (Figure 2). This merely reflects the fact that the poorwill activity was restricted to open side hills and forest edges. 
Table 1: Calling Data by Transect

\begin{tabular}{|c|c|c|c|c|c|c|c|}
\hline $\begin{array}{l}\text { Transect } \\
\text { Number }\end{array}$ & $\begin{array}{l}\text { Transect } \\
\text { Name }\end{array}$ & $\begin{array}{l}\text { Transect } \\
\text { Length } \\
(\mathrm{km})\end{array}$ & $\begin{array}{l}\text { Number } \\
\text { Calling } \\
\text { Nights }\end{array}$ & Dates & $\begin{array}{l}\text { Birds } \\
\text { Heard }\end{array}$ & $\begin{array}{l}\text { Birds } \\
\text { Seen }\end{array}$ & $\begin{array}{l}\text { Minimum } \\
\text { Number } \\
\text { Males }\end{array}$ \\
\hline 1 & $\begin{array}{l}\text { south of } \\
\text { Fort Walsh }\end{array}$ & 0.5 & 1 & 23 May & 0 & 0 & 0 \\
\hline 2 & $\begin{array}{l}\text { Farwell's } \\
\text { Post }\end{array}$ & 2.0 & 2 & $\begin{array}{l}26,30 \\
\text { May }\end{array}$ & 0 & 0 & 0 \\
\hline 3 & Hwy $615 n$ & 3.7 & 5 & $\begin{array}{l}27,29, \\
31 \text { May } \\
2,5 \text { June }\end{array}$ & 8 & 0 & 6 \\
\hline 4 & $\begin{array}{l}\text { sw of } \\
\text { station }\end{array}$ & 0.5 & 10 & $\begin{array}{l}28,30 \\
\text { May } \\
1,6,7, \\
11,14,24, \\
26 \text { June } \\
21 \text { July }\end{array}$ & 15 & 7 & 3 \\
\hline 5 & Hwy $615 \mathrm{~s}$ & 6.0 & 5 & $\begin{array}{l}\text { 27, 29, } \\
31 \text { May } \\
23,25 \text { June }\end{array}$ & 0 & 0 & 0 \\
\hline 6 & Station & 0.5 & 8 & $\begin{array}{l}1,10, \\
14,17,24, \\
25 \text { June } \\
3,5 \text { July }\end{array}$ & 12 & 2 & 4 \\
\hline 7 & $\begin{array}{l}\text { Mystery } \\
\text { Rocks }\end{array}$ & 0.5 & 2 & $\begin{array}{l}9,13 \\
\text { June }\end{array}$ & 7 & 1 & 4 \\
\hline 8 & Hwy 21 & 2.5 & 1 & 8 June & 0 & 0 & 0 \\
\hline 9 & $\begin{array}{l}\text { Battle } \\
\text { Creek Rd. }\end{array}$ & 4.25 & 1 & 12 June & 1 & 0 & 1 \\
\hline 10 & $\begin{array}{l}\text { La Barge } \\
\text { Trail }\end{array}$ & 8.0 & 1 & 15 June & 0 & 0 & 0 \\
\hline 11 & $\begin{array}{l}\text { South } \\
\text { Benson Trail }\end{array}$ & 3.0 & 1 & 16 June & 0 & 0 & 0 \\
\hline 12 & $\begin{array}{l}\text { Shaefer } \\
\text { Road }\end{array}$ & 17.6 & 1 & 18 June & 0 & 0 & 0 \\
\hline 13 & $\begin{array}{l}\text { North } \\
\text { Benson Trail }\end{array}$ & 4.1 & 2 & $\begin{array}{l}17,19 \\
\text { June }\end{array}$ & 0 & 0 & 0 \\
\hline 14 & $\begin{array}{l}\text { Fire Tower } \\
\text { Road }\end{array}$ & 11.3 & 1 & 28 July & 8 & 1 & 8 \\
\hline 15 & $\begin{array}{l}\text { sw corner } \\
U \text { of } R \\
\text { property }\end{array}$ & 0.5 & 4 & $\begin{array}{l}6,15 \text { June } \\
16,25 \text { July }\end{array}$ & 3 & 6 & 1 \\
\hline 16 & $\begin{array}{l}\text { Ranger } \\
\text { Station Road }\end{array}$ & $d^{6.0}$ & 5 & $\begin{array}{l}12 \text { June } \\
2,7,8,9 \text { July }\end{array}$ & $y^{5}$ & 6 & 3 \\
\hline Total & & & & & & & $\overline{30}$ \\
\hline
\end{tabular}


Table 2: Summary of Data for Captured Poorwills.

The latitude and longitude coordinates are from topographical map 72F/12.

$\begin{array}{lllll}\text { Date } & \text { Place } & \text { Sex } & \begin{array}{l}\text { USFWS Band } \\ \text { Number }\end{array} & \text { Mass }(g) \\ 05 / 07 / 91 & \begin{array}{l}49^{\circ} 34^{\prime} 02^{\prime \prime} \mathrm{N} \\ 109^{\circ} 53^{\prime} 50^{\prime \prime} \mathrm{W}\end{array} & \text { male } & 891-29902 & 44.0 \\ & & & \\ 15 / 07 / 91 & \begin{array}{l}49^{\circ} 34^{\prime} 02^{\prime \prime} \mathrm{N} \\ 109^{\circ} 53^{\prime} 50^{\prime \prime} \mathrm{W}\end{array} & \text { female } & 891-29903 & 54.0\end{array}$

\section{DISCUSSION}

Population Size From playbacks, we conservatively estimate that a minimum of 30 male or 60 poorwills were resident in the West Block. This estimate represents a conservative figure since some of the locations where poorwills may have been present were not surveyed due to their inaccessibility. Also, the number of birds heard calling is dependent upon climatic factors. Rain, wind, etc., impair the ability to hear calling birds and it is possible that inclement weather may result in reduced vocalization on the part of the birds.

Calling by poorwills stopped in mid-July for unknown reasons. This behaviour contrasts that of the Okanagan population, where birds continue to call (unsolicited) throughout the summer and into the fall (R.M. Brigham, unpub. data). The lack of calling by birds in the Cypress Hills population may have contributed to previous observers concluding that the Cypress Hills population was sporadic in occurrence. ${ }^{13}$ Poorwill calling appears to be dependent on season (most intense in late spring/early summer; least intense in mid- to late summer).

Reproductive Status The two nests we found are the second and third records for this species in the Cypress Hills and in Saskatchewan. ${ }^{14}$ The fact that the only pair we radio-tagged was reproductively active suggests that much of the population is. Assuming that the tagged pair was typical, birds in the Cypress Hills make two nesting attempts, the same as in the Okanagan.

Although both Canadian populations of poorwills occur at the northern limit of their range, the Cypress Hills is an area with a more continental climate than the Okanagan Valley. This is likely reflected in the later arrival (approximately two weeks in 1991) of poorwills in the Cypress Hills. Future work is needed to address the question of whether climatic differences influence the use of torpor in the two areas.

Habitat Use Unlike the Okanagan, foraging poorwills were regularly found near or tracked to forest edges rather than just open grassy areas. Further, poorwills in the Cypress Hills appear to roost/nest in areas with more ground cover and longer grass than in British Columbia.

Poorwills do not appear to be restricted by the elevation of potential habitats. The Okanagan Valley population is centred at elevations approaching 500 and $1000 \mathrm{~m}$ a.s.l. ${ }^{3}$ In contrast, poorwills in the Cypress Hills population were regularly heard at elevations approaching $1300 \mathrm{~m}$ (e.g., individuals along the Fire Tower road: Figure 2), which is close 
to the highest point of the Cypress Hills in Saskatchewan.

In conclusion, we found evidence of a significant population of poorwills in the West Block of the Cypress Hills. The degree of reproductive success and whether this population is stable over time remain to be determined.

\section{Acknowledgements}

We thank all of the landowners in the West Block who allowed access to their property; especially the Hansons and Blacks and the staff at the Fort Walsh National Historic Site. We gratefully acknowledge the Biology Department, University of Regina, for the use of the field station and Drs. D. and M. Sauchyn for the observations of 22 September. This study was funded by Saskatchewan Environment and Public Safety through the Environmental Youth Corps program; grants from the Saskatchewan Natural History Society, the University of Regina's President's Natural Sciences and Engineering Research Council (NSERC) fund, and an NSERC operating grant to $R$.

$M$. Brigham.

1. ALDRICH, E.C. 1935. Nesting of the Dusky Poor-will. Condor 37:49-55.

2. BARTHOLOMEW, G.A., T.R. HOWELL and T.J. CADE. 1957. Torpidity in the White-throated Swift, Anna Hummingbird, and Poor-will. Condor 59:145-155.

3. BRIGHAM, R.M. Daily torpor in a free ranging goatsucker, the Common Poonwill (Phalaenoptilus nuttallii). Physiol. Zool. In press.
4. BRIGHAM, R.M. and R.M.R. BARCLAY. Lunar influence on the foraging and nesting activity of the Common Poorwill (Phalaenoptilus nuttallii; Caprimulgidae). Auk. In press.

5. CAMPBELL, R.W., N.K. DAWE, I. MCTAGGART-COWAN, J.M. COOPER, G.W. KAISER and M.C. MCNALL. 1990. The birds of British Columbia. Vol. 2. Royal British Columbia Museum, Victoria. $636 \mathrm{pp}$.

6. CANNINGS, R.A., R.J. CANNINGS and S.G. CANNINGS. 1987. Birds of the Okanagan Valley, British Columbia. Royal British Columbia Museum, Victoria. 420 pp.

7. GODFREY, W.E. 1986. The birds of Canada. National Museum of Natural Sciences, Ottawa. 595 pp.

8. JAEGER, E.C. 1948. Does the poor-will "hibernate?" Condor 50:45-46.

9. KEPLER, C.B. and A.K. KEPLER. 1973. The distribution and ecology of the Puerto Rican Whip-poor-will, an endangered species. Living Bird 12:207-239.

10. MILLS, A.M. 1986. The influence of moonlight on the behaviour of goatsuckers (Caprimulgidae). Auk 103:370-378.

11. NELSON, J.G. 1973. The last refuge. Harvest House, Montreal.

12. ORR, R.T. 1948. Nesting behaviour of the poor-will. Auk 65:46-54.

13. SMITH, A.R. and C.I.G. ADAM. An atlas of Saskatchewan birds. Canadian Wildlife Service and Saskatchewan Natural History Society, Regina. In press.

14. SUTHERLAND, H. 1984. The first nesting Common Poorwill in Saskatchewan. Blue Jay 42:224-225. 